\title{
Advances in managing medulloblastoma and intracranial primitive neuro-ectodermal tumors
}

\author{
Jenny Adamski ${ }^{1}$, Vijay Ramaswamy ${ }^{2}$, Annie Huang ${ }^{1,2}$ and Eric Bouffet ${ }^{1}$ *
}

\author{
Addresses: ${ }^{1}$ Division of Haematology/Oncology, The Hospital for Sick Children, 555 University Avenue, Toronto, Ontario M5G 1X8, Canada; \\ ${ }^{2}$ Arthur and Sonia Labatt Brain Tumour Research Centre, Brain Tumour Research Centre, TMDT, 101 College St., 11-701, Toronto, Ontario \\ M5G 1L7, Canada \\ *Corresponding author: Eric Bouffet (eric.bouffet@sickkids.ca) \\ Fl000Prime Reports 2014, 6:56 (doi:10.12703/P6-56) \\ All F1000Prime Reports articles are distributed under the terms of the Creative Commons Attribution-Non Commercial License \\ (http://creativecommons.org/licenses/by-nc/3.0/legalcode), which permits non-commercial use, distribution, and reproduction in any medium, \\ provided the original work is properly cited. \\ The electronic version of this article is the complete one and can be found at: http://f1000.com/prime/reports/m/6/56
}

\begin{abstract}
Medulloblastoma and central nervous system (CNS)-primitive neuro-ectodermal tumors (PNETs) are a diverse group of entities which encompasses different pathological and clinical pictures. Initially divided based on histology and location, molecular insight is leading to new definitions and a change in the borders delineating these diseases, such that they become more divergent. Current treatment approaches consist of surgical resection, radiotherapy and intensive chemotherapy, dependent on age. Stratification is one risk factor shown to be prognostic and is divided into high- and average-risks. Outcomes with modern treatment regimens are good, particularly in average-risk medulloblastoma patients, but the cost of cure is high, with high rates of neurocognitive, endocrine and social dysfunction. The changing biological landscape, however, may allow for clearer prediction of tumor behavior, to better identify "good" and "bad" players within these groups. Discovery of subgroups with changes in dependent molecular pathways will also lead to the development of new specific targeted therapies. Presenting exciting opportunities, these advances may transform the treatment for some patients, revolutionizing therapy in the future. Several challenges, however, are yet to be faced and caution is needed not to abandon previously defined prognostic factors on the strength of thus far retrospective evidence. We are witnessing a new era of trials with biological stratification involving multiple subgroups and treatment arms, based on specific tumor-related targets. This review discusses the changing face of medulloblastoma and CNS-PNETs and how we move molecular advances into clinical trials that benefit patients.
\end{abstract}

\section{Introduction}

A PNET is a small, blue, round cell tumor comprising primitive, undifferentiated cells of neuro-ectoderm origin. Mainly occurring in children and adolescents, PNETs were initially thought to arise from the same cell of origin and divide in the CNS by location into infratentorial and supra-tentorial PNETs [1,2]. The term infratentorial PNET was used synonymously with medulloblastoma, until medulloblastoma was recognized as genetically distinct, rather than just a PNET occurring in the posterior fossa [3]. The current World Health Organization (WHO) classification (2007) divides embryonal tumors into medulloblastoma and
CNS-PNETs, not specifying supratentorial in recognition of their occurrence in the posterior fossa, brainstem and spinal cord, not just above the tentorium [2]. Atypical teratoid rhabdoid tumors (ATRTs), although within the umbrella of embryonal tumors, are distinguishable based on INI1/SMARCB1 negative staining and are not the subject of this review. Further subdivision of both medulloblastoma and CNS-PNET is currently based on histological features. Advances in molecular genomics have allowed identification of distinct medulloblastoma subgroups [4-7]. By 2012 a consensus arose to classify four subgroups of medulloblastoma based on their transcriptional profile [8]. Characterization of these 
subgroups continues to evolve, and groups can now be described in terms of epidemiology, clinical features, histology, cell of origin, location within the posterior fossa, behavior, response to treatment and prognosis. Similar analyses of CNS-PNETs showed three subgroups which are molecularly and clinically distinct [9]. Although less well characterized, these subgroups of CNS-PNET collate patients in a way that defines their clinical behavior and may lead to dramatic changes in the management of CNS-PNET.

Currently, treatment for both medulloblastoma and CNS-PNETs is based on age and risk group. Children older than 3-4 years are treated with surgery, radiotherapy and chemotherapy, based on their risk defined by the presence of metastatic disease, residual disease or histology. Infants and young children under 3-4 years old are treated with radiation-sparing approaches involving intensive chemotherapy regimens. CNS-PNETs have historically been treated on medulloblastoma protocols. As the outcomes for this group of patients is worse, they have been automatically stratified to the high-risk arms. With the recognition that it is biology rather than histology that is important when dictating behavior, future trials plan to stratify based on molecular subgrouping. This review discusses the current management of medulloblastoma and CNS-PNETs, advances in our understanding of the biology of these tumors and what future treatment may look like.

\section{The clinical management today Medulloblastoma}

Medulloblastoma is the most common malignant brain tumor of childhood, accounting for approximately $20 \%$ of pediatric brain tumor patients [10]. It arises in childhood and adolescents, with 70\% of patients presenting before 16 years, and has a male preponderance of approximately $65 \%$ [2]. Children generally present with headache, early morning vomiting or ataxia. An enhancing heterogeneous posterior fossa mass is detected on imaging, hypointense on T1 weighted magnetic resonance imaging (MRI) scan and hyperintense on T2 weighted MRI scan, with increased diffusion restriction (see Figure 1). More than $75 \%$ of tumors arise centrally from the cerebellar vermis, although in older children there is a higher incidence of tumors laterally within the cerebellar hemispheres [2]. Staging is completed with spine imaging and cerebrospinal fluid examination, and classified according to the Chang staging system from non-metastatic disease (M0) to extraneural metastasis (M4 - see Table 1 [11]), with approximately one third of children having metastatic disease at presentation [2]. The $2007 \mathrm{WHO}$ classification recognizes five subtypes; classical medulloblastoma, desmoplastic nodular medulloblastoma, medulloblastoma with extensive nodularity
Figure I. MRI images of medulloblastoma

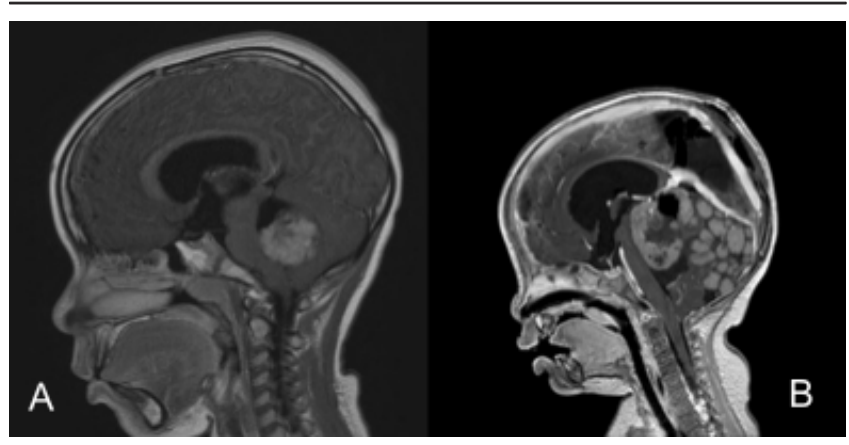

TI weighted magnetic resonance imaging (MRI) images are shown following contrast administration. A) shows an axial image of a 6 year old child with a classical medulloblastoma. B) shows an axial image of an 8 month old child with medulloblastoma with extensive nodularity (MBEN).

Table I. The Chang staging system for medulloblastoma

\begin{tabular}{ll}
\hline Chang Staging & Description of Staging \\
\hline M0 & No evidence of metastasis \\
MI & Tumor cells found in cerebrospinal fluid \\
M2 & Intracranial tumor beyond primary site \\
M3 & Gross nodular seeding in spinal subarachnoid space \\
M4 & Metastasis outside the cerebrospinal axis (especially \\
& to bone marrow, bone) \\
\hline
\end{tabular}

(MBEN), anaplastic medulloblastoma and large cell medulloblastoma [2].

Clinical trials have identified clinical prognostic factors that are the foundation on which current treatments are based; age, metastatic status, extent of resection and, more recently, histology. Both favorable biological markers, such as monosomy 6 , and unfavorable, such as MYC or MYCN amplification, and isochromosome $17 q$ have been identified [12]. Only the identification of MYC amplification has been prospectively shown to be an independent prognostic factor significant enough to use as a base for future risk stratification [13]. Management is divided into separate approaches for infants and older children.

The management of infant medulloblastoma

Stratification based on age comes as a result of two intertwined factors, the need to treat infants differently and poorer survival in this group of patients. The outcome for infants is significantly poorer than in older children [14]. This may stem from the reluctance to use intensive treatment regimens in babies and the avoidance of radiotherapy, due to the unacceptable neuro-cognitive consequences. Exceptions are infants with MBEN and desmoplastic medulloblastoma, which have excellent survival rates of greater than $80 \%$. Currently infants are 
treated with radiation-sparing approaches, which have been improved by using dose intensive regimens with or without autologous stem cell rescue [15-19]. These studies attempt to avoid radiation, reserving it for a salvage strategy. Attempts to avoid craniospinal radiation (by substituting focal radiation in infants) resulted in a high rate of distant relapse and failed to demonstrate improved outcome over chemotherapy alone [20]. As the majority of infants do not receive radiotherapy as their first-line treatment, the salvage rate is significant following relapse when compared to older children [17].

\section{The management of medulloblastoma in older children}

Treatment in older children is stratified into high- and average-risk groups, depending on clinical prognostic markers. The most significant prognostic factor following age is the presence of metastatic disease, classifying these patients as high-risk. The extent of surgical resection is important and the consensus is that surgery should be as extensive as safely achievable [21]. A residual tumor volume of less than $1.5 \mathrm{~cm}^{2}$ is prognostic, and this figure has been used to stratify patients in recent studies [22]. Its value, however, is only recognized in M0 disease and uncertain in those with metastatic disease. Some protocols also consider histology and include large cell medulloblastoma or diffuse anaplasia as high-risk. The treatment implication is a reduction of craniospinal radiation for average-risk patients in comparison to highrisk patients, and prospective trials have concentrated on reducing this from the full dose of $36 \mathrm{~Gy}$ to 23.4Gy [23]. Currently the open randomized Children's Oncology Group trial ACNS0331 is investigating a further reduction to 18Gy [23]. Radiation is followed by platinumbased chemotherapy regimens, either in intensive but conventional schedules or as high-dose therapy with stem cell rescue. These approaches have successfully driven 5-year progression-free survival above $80 \%$ in average-risk patients $[23,24]$. Successful treatment, however, comes at considerable cost. Survivors show endocrine dysfunction, hearing loss, premature aging, increased risk of stroke and secondary malignancy and, most significantly, deterioration in neurocognitive function, which is progressive with time and results in significant intellectual and social dysfunction [25]. Although reduced radiation doses and the increasing use of tumor bed boost instead of the whole posterior fossa boost have lessened the drop in IQ, the deficit remains significant and results in a considerable reduction in the quality of life [26,27]. Proton therapy may in the future minimize the long-term morbidity of craniospinal radiation, particularly in terms of growth, and cardiac and pituitary function, but, as the cranial dose is similar, this may not translate into improved neurocognitive outcome [28]. Limited success has been achieved in the treatment of patients with high-risk disease with 5 -year overall survival ranging from $40 \%$ to $82 \%$ [24,29-32]. Strategies then aim to improve outcomes rather than reduce long-term effects and have included intensifying treatment with higher doses of radiotherapy, hyperfractionation and the use of radio-sensitizers. Recurrent medulloblastoma in older children has a dismal outcome with a salvage rate of $<10 \%$, irrespective of the treatment modality used. A hope of cure after relapse is limited to patients where recurrence is localized and amenable to surgical resection, chemo-sensitivity is demonstrated or re-irradiation is possible $[33,34]$.

\section{CNS-PNETS}

CNS-PNETs make up approximately $2.5 \%$ of brain tumors in pediatric patients [2]. Although mainly situated within the cerebral hemispheres, they occur anywhere within the CNS including the posterior fossa, brain stem and spinal cord. Pineal lesions were once classified under the umbrella of CNS-PNETs but evidence suggests that they are genetically distinct and therefore are now referred to separately as pineoblastoma $[2,35]$. The $2007 \mathrm{WHO}$ criteria define four subtypes of CNS-PNET: CNS neuroblastoma; CNS ganglioneuroblastoma; medulloepithelioma and ependymoblastoma (see Figure 2). More recently the ETANTR (embryonal tumor with abundant neuropil and

\section{Figure 2. MRI images of CNS-PNET}

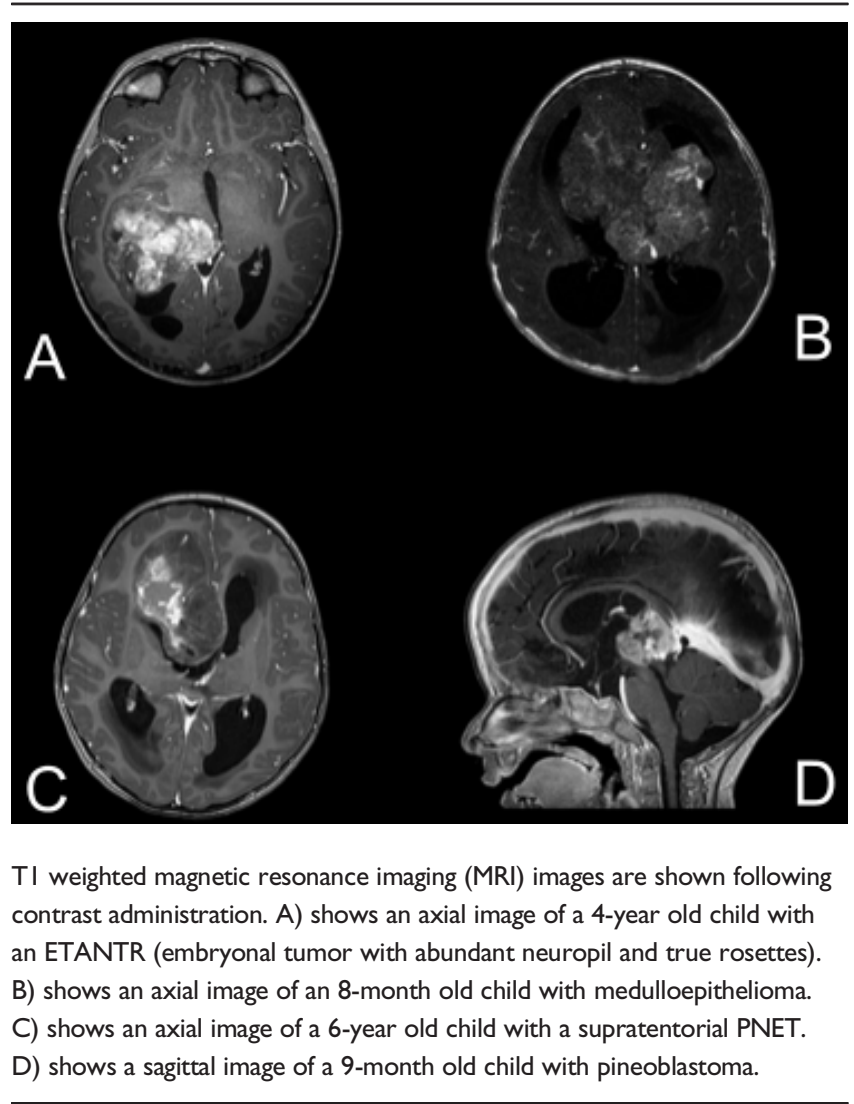


true rosettes) has been recognized as a new entity within this subgroup [36]. Outcome across these histological variants is not uniform. ETANTRs and intracranial medulloepithelioma have a particularly poor survival rate, with disease progressing during treatment in many children and a median survival of 9 months [9]. As the molecular definition of CNS-PNETs becomes more refined, biological prognostic factors are being identified. Tumors with increased complexity of genomic copy number abnormalities and chromosome 19 microRNA cluster (C19MC) amplified tumors have a worse outcome $[9,37,38]$. Because of the rarity of the disease and the histological similarity to medulloblastoma, children with CNS-PNETs have traditionally been treated on protocols alongside medulloblastoma, utilizing surgical resection, craniospinal radiation and chemotherapy. For the purpose of management they can be considered as three different groups: infants with CNS-PNETs or pineoblastoma; older children with CNS-PNETs; and older children with pineoblastoma.

Approaches to infants with CNS-PNETs and pineoblastoma are similar to approaches to infant medulloblastoma. Dose-intensive chemotherapy regimens, including high dose chemotherapy with autologous stem cell rescue, have been used to attempt to avoid or delay radiation [39-42]. Survival, however, remains poor with 3-5 year event-free survival between 0 and 39\% and overall survival between 0 and 49\% [39,41,42]. Radiation is considered by many to be essential for cure [41-44].

Older children with CNS-PNETs comprise a very small group of patients. Treated alongside medulloblastoma their outcome is generally poorer on the same protocols, with 3-5-year event-free survival between 17 and 60\% and overall survival between 15 and 73\% [39,44-49]. Thus, CNS-PNETs are generally stratified to high-risk arms. Due to the mainly retrospective nature of the data on CNS-PNETs, and the small patient numbers, few prognostic factors have been confirmed and contradictions exist within the literature. The extent of resection has failed to reach significance as a prognostic factor $[44,48,49]$ and metastasis is reported as having a negative impact by some [46], but not all series $[39,44]$. Despite this, risk stratification based on the extent of surgical resection, the presence of metastasis, and the response to chemotherapy, has enabled successful reduction of craniospinal radiation or implementation of focal radiation in selected patients $[45,47]$.

Like CNS-PNET, pineoblastoma in older children are treated as high-risk medulloblastoma. Outcome is found by most to be better in the pineal region than for CNSPNETs in other sites, with 3-5-year event-free survival between $38 \%$ and $69 \%$ and overall survival between $61 \%$ and $83 \%[41,46-49]$. Surgical resection is often limited by the accessibility of the pineal region. However, even with significant residual disease some patients have been successfully treated with reduced radiation, suggesting a more favorable course and the ability to reduce therapy in selected cases [45].

\section{Where are the boundaries now? Molecular definition of subgroups}

There are four accepted subgroups of medulloblastoma (reviewed in $[8,50]$ - see Figure 3, reproduced from [8]) and three suggested subgroups of CNS-PNETs [9]. Differentiated by key transcriptional profiles, each is distinct in terms of genetics, clinical features and behavior.

\section{WNT medulloblastoma}

The WNT group implicates the WNT pathway in the pathogenesis and represents approximately $10 \%$ of medulloblastoma patients. They have an activated WNT pathway, primarily through an activating mutation in exon 3 of CTNNB1a, which leads to nuclear accumulation of the WNT pathway effector $\beta$-catenin [51]. Intranuclear immunohistochemistry for $\beta$-catenin, sequencing of exon 3 of CTNNB1 or identification of monosomy 6 are all used as markers of WNT tumors [51,52]. However, monosomy 6 can also be observed in other subgroups and should not be used in isolation. WNT tumors occur in older children and adolescents, with a sex ratio of 1:1. The majority of patients have classical histology, although large cell anaplastic variants are found [51]. With current treatment approaches, the outcome of WNT medulloblastoma patients is excellent, with survival rates greater than $95 \%[51,52]$.

\section{Sonic hedgehog medulloblastoma}

The sonic hedgehog medulloblastoma has somatic alterations within the sonic hedgehog signaling pathway, of which many have been identified including mutations in PTCH1, PTCH2, SUFU, and SMO [53-57]. Amplifications of GLI2 and MYCN are also frequently observed [58]. They make up 30\% of medulloblastomas and are distinguished by gene expression profiling or SFRP1 or YAP1 immunohistochemistry $[6,13]$. Sonic hedgehog tumors have a bimodal age distribution, occurring in infants ( $<3$ years) or adults ( $>16$ years), both groups of which are likely to be genetically distinct with different pathway mutations [59]. Again the sex ratio is $1: 1$ and disease is frequently localized, particularly in infants. Patients with nodular desmoplastic medulloblastoma and MBEN almost exclusively lie within the sonic hedgehog group of tumors. However, all histological variants are represented within this group, and approximately $50 \%$ of patients have other histology such as classical or Large Cell Anaplastic (LCA). Patients with sonic hedgehog pathway alterations have a variable prognosis. Reports have identified a subgroup of 
Figure 3. Medulloblastoma subgrouping

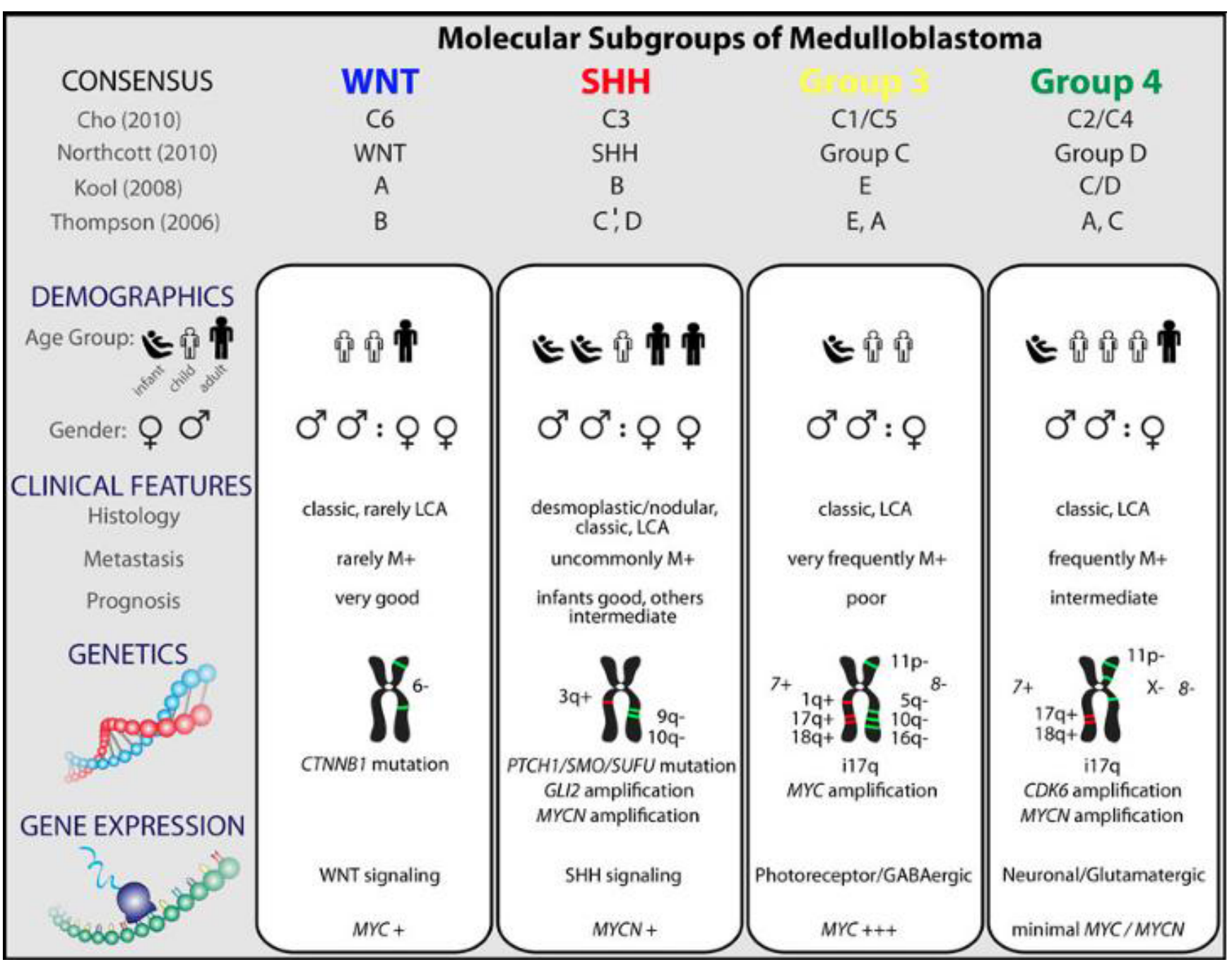

The current consensus on medulloblastoma subgrouping reproduced from Taylor et al. 2012 [8]. SHH, sonic hedgehog.

sonic hedgehog patients, with p53 mutated tumors, who show a high rate of early failure [60], yet, in contrast, desmoplastic tumors have an excellent outcome and infants may be successfully treated without the use of radiation [18].

\section{Group 3 medulloblastoma}

As yet no dominant signaling pathway has been implicated in the pathogenesis of group 3 medulloblastoma, although frequent aberrations in the TGF1 beta pathway have been identified [58]. This group possesses the worst prognosis of all of the medulloblastoma subgroups [4]. Patients are infants or children, rarely teenagers and never adults. They often have metastatic disease on presentation (particularly in infants where it approaches 50\%), and tumors have aggressive behavior, progressing sometimes irrespectively of the treatment used. Nearly all MYC amplified tumors are contained within this subgroup as is a frequent fusion between PVT1-MYC, leading to very high MYC expression [58]. The most common cytogenetic aberration is isochromosome $17 \mathrm{q}$ but gains of chromosomes $1 \mathrm{q}$ and 7 , and deletions of $10 \mathrm{q}, 11,16 \mathrm{q}$ and $17 \mathrm{p}$ are frequently observed.

\section{Group 4 medulloblastoma}

Group 4 tumors represent the majority of tumors in medulloblastoma patients. Patients are typically children and more commonly boys (ratio 3:1). Metastatic dissemination is frequent at diagnosis in approximately 30\% of patients. Group 4 tumors have mostly classical histology, 
although LCA tumors are seen, and the majority of patients have isochromosome 17q. Prognosis within this group, like the sonic hedgehog tumors, is heterogeneous. Patients can be divided into "poor" and "good" prognostic subtypes on the basis of follistatin-related protein 5 (FSTL5) expression which, if high, carries a poorer prognosis [61]. MYCN rather than MYC amplifications are commonly observed and the most common structural alteration in this subgroup is a tandem duplication of SNCAIP [58]. Single nucleotide variations in the histone demethylase KDM6A are primarily found in group 4 [55-57].

\section{CNS-PNETs}

Although characterization of CNS-PNETs is in its infancy, three molecular subgroups have been defined based on transcriptional signatures, reflecting different cellular origins [9]. Group 1 enriches for neural stem cell genes, group 2 has more oligoneural markers and group 3 more mesenchymal differentiation genes. Group 1 tumors are identified by amplification of the C19MC at chr19q13.41-42 and positivity for LIN28, a pluripotency gene $[62,63]$. LIN28 positivity on immunohistochemistry serves as a marker for group 1 tumors and likewise OLIG2, a marker of motor neuron and oligodendrocyte differentiation, serves as a marker for group 2 tumors. Although IGF2 was found to be differentially expressed in group 3 tumors, no specific marker could be validated on immunohistochemistry and these tumors by default are identified as LIN28/OLIG2 negative [9]. Markers cannot be used in isolation as, although C19MC amplification is not seen in other CNS tumors, LIN28 positivity is described in other primary CNS tumors, including ATRTs. Correlation with histology and other biological markers, such as INI1/SMARCB1 is needed [64]. Clinical distinctions between the subgroups are clear. Group 1 patients are significantly younger than those in group 2 and 3 and mostly located within the cerebellum, brain stem and spine as opposed to the cerebral hemispheres [64]. Group 1 also has dismal survival with the median survival being 0.8 years compared with 1.8 years in group 2 and 4.3 years in group 3. Group 3 patients are more likely to present with metastasis (53\% compared to $20 \%$ in both other groups combined) yet, despite this, may have a better survival.

\section{Does biology rule?}

One pertinent question is how we navigate the new biological landscape and reconcile it with our past knowledge. In a meta-analysis combining data from seven separate medulloblastoma studies, subgroup allocation was of significant prognostic value, suggesting it is primarily biology that matters [65]. Retrospective analyses may help validate the prognostic capabilities of subgrouping, but do not provide enough evidence to abandon the previously defined prognostic factors on which treatment decisions are made.

In CNS-PNETs, data suggest the C19MC amplicon and LIN28 positivity define a group of patients with a dismal outcome $[9,63,64]$. The transcriptional and methylation profiles of these patients with C19MC/LIN28 positivity suggest a single biological entity despite variant histology $[64,66]$. What is not known is to what extent negativity for C19MC/LIN28 conveys a better outcome, for instance within the group of infants with ETANTR [9,64,67].

Retrospective analyses of subgroups in relation to important prognostic factors are required. Only then can one validate whether subgroups override previous prognosticators. It is likely there will be a shift in our understanding with newly defined "good" high-risk patients as well as "bad" average-risk patients.

\section{Treatment of medulloblastoma and CNS-PNET tomorrow}

Subgrouping of patients may more accurately define our patient groups (see Figure 4, adapted from [68]). It could change our notion of current risk groups and more accurately predict prognosis. Subgroup specific cytogenetic biomarker-driven stratification has recently been shown to retrospectively predict survival, advocating for biology-driven risk stratification [69]. However, subgrouping is not a tool for stratification but for a change in treatment. Future cooperative trials will integrate the current knowledge regarding the molecular biology of medulloblastoma and develop group-specific therapies. The first patients considered for these trials are the WNT patients and the sonic hedgehog patients because of the ease of identification of these patients and apparent clinical rationale for a change in treatment.

WNT patients have a >95\% 5-year survival with current treatment strategies, suggesting they are being overtreated as a group [65]. Future strategies for these patients will concentrate on de-escalating treatment to lessen the burden of treatment-related morbidity. Such strategies cannot be taken lightly in a disease that has a negligible salvage gap and brave steps are required to omit therapies as entrenched as craniospinal radiation. Further work is also necessary to define whether there are any higher risk patients within the WNT group who should not be down-graded.

Within the sonic hedgehog pathway, druggable targets exist for which new agents are already in advanced stages 
Figure 4. The future treatment of medulloblastoma

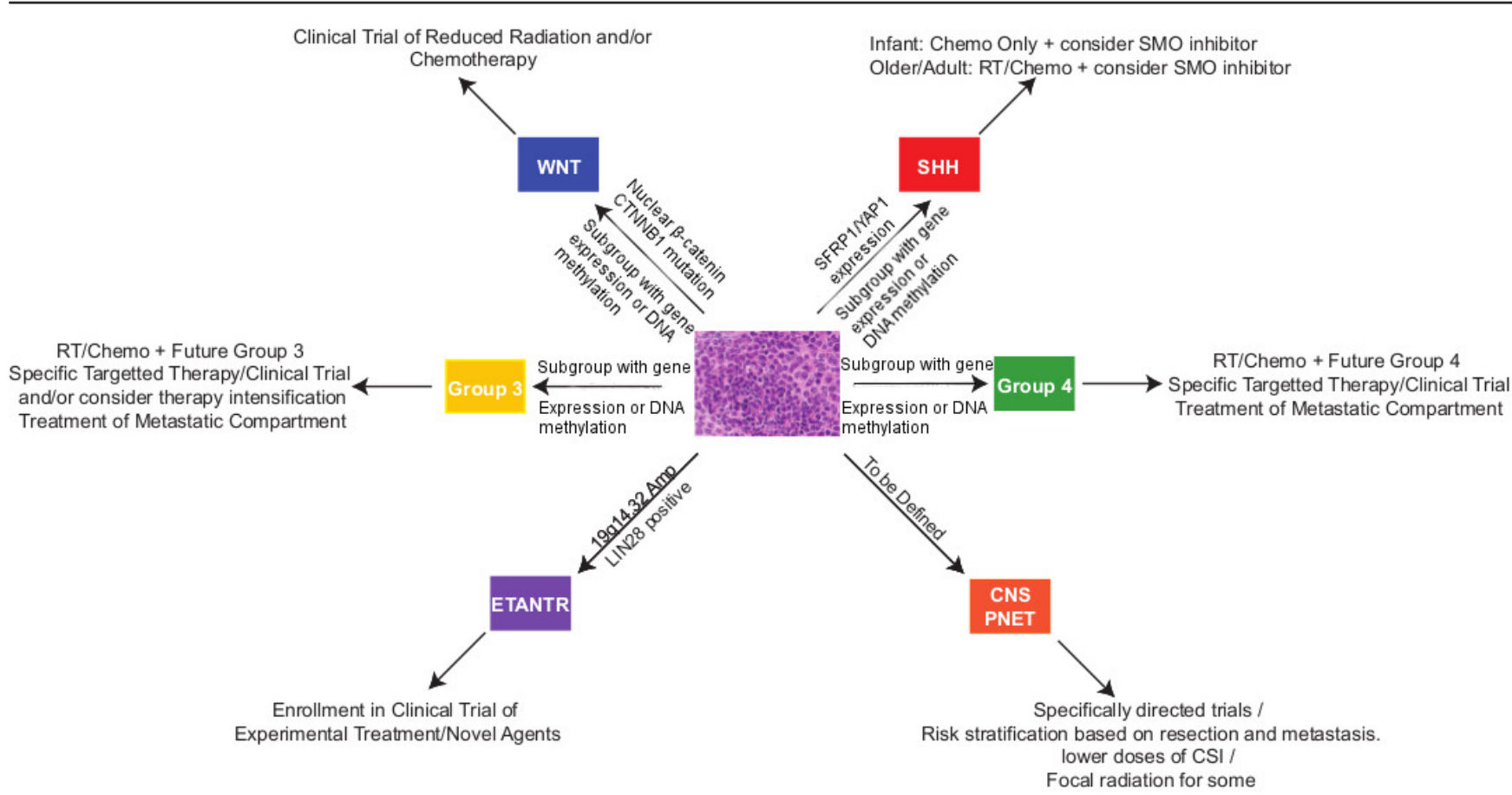

Proposed future treatments based on molecular subgrouping adapted from Ramaswarmy et al. 201 I [68]. CSI, craniospinal radiation; CNS-PNET, central nervous system primitive neuro-ectodermal tumor; ETANTR, embryonal tumor with abundant neuropil and true rosettes; SHH, sonic hedgehog.

of development. The smoothened inhibitors LDE225 and GDC-449 show promise and the former is currently in phase III trials (NCT01878617). There is still much to learn, however. Subtypes within the sonic hedgehog group have mutations at different parts of the sonic hedgehog pathway, suggesting the choice of sonic hedgehog inhibitor will be dependent on specific subtypes [70].

Molecularly targeted treatment options are not yet available to group 3 or 4 medulloblastoma patients. For these patients, initial approaches may use new prognostic factors to direct innovative therapies. Subtypes of extremely poor prognosis patients identified within the subgroups, such as infants with group 3, MYC amplified tumors or p53 positive sonic hedgehog tumors, should be considered for experimental agents. Validation of clinical variables between subgroups may also influence how we design future clinical trials. The knowledge that the majority of group 3 and 4 patients are metastatic at recurrence may lead us to direct treatment at the metastatic compartment in these patients. In contrast, sonic hedgehog patients are more commonly localized at recurrence so, in this group, the emphasis should be on local control and it may be that craniospinal radiation can be reduced further [71].

The future of CNS-PNET treatment lies in their segregation into specifically directed protocols. To date there have been few prospective CNS-PNET trials and no trials where the treatment of CNS-PNET differed from medulloblastoma [46]. International collaboration is required to design trials explicitly for CNS-PNET. The first steps are to better define the clinical and biological spectrum of the disease, with molecular profiling of larger cohorts with correlated clinical details. Currently, we know LIN28positive patients do poorly on current therapy, irrespective of the location of their tumor or the extent of resection. These initial trials could begin to address controversies in the management of these patients, such as the need for high-risk approaches for all CNS-PNET patients. The data from St. Jude and confirmed by the Milan group suggest that patients can be risk-stratified based on resection and metastatic status, and a proportion treated successfully with lower doses of craniospinal radiation or even focal radiation $[45,47]$. Such an approach is also supported by the retrospective clinical observations that local relapse is more common in CNS-PNETs $[43,48]$. 
Armed with more biological characterization, we may be able to base clinical decisions on biology and incorporate subgrouping to stratify patients as confidently as we do in medulloblastoma.

\section{Clouds on the horizon}

Ideally, patients with medulloblastoma or CNSPNETs should undergo real-time diagnosis of their molecular subgroup in order to have individual treatment tailored to their biological risk, from surgery to radiation to chemotherapy. Many questions need to be answered before this becomes a reality.

The technical aspect of viable and affordable subgrouping in a clinical setting is yet to be validated. The speed of progression in molecular advances may make techniques outdated before they can be implemented clinically. Although RNA-based genome-wide transcriptional profiling has been the gold standard for subgroup allocation, high-resolution DNA methylation profiling may surpass transcriptional profiles for subgrouping prior to their routine use, due to the robustness and reproducibility of this assay, coupled with its reliability from formalin fixed paraffin embedded (FFPE) samples [72]. The need for frozen tissue for gene expression arrays precludes them from routine clinical use, particularly in prospective clinical trials. The added expense of DNA methylation arrays, however, makes them less accessible. One solution is to use the nanoString nCounter, which provides reliable gene expression profiling from FFPEderived RNA, with high correlation to matched frozen tissue using a 22 gene signature [73]. A consensus on methodology and knowledge on the reproducibility of defining subgroups must be reached in order to compare clinical trials. The feasibility of molecular diagnosis in time to be clinically relevant will be tested prospectively in the upcoming COG and SIOP trials [70].

For the clinical trialists there are major challenges to overcome. Knowledge advances with such speed that a trial becomes outdated before completion. This is especially true given the complexity subgrouping brings. It is becoming clear that subtypes exist within subgroups [69]. How to integrate this knowledge within clinical trials requires careful consideration given the limited patient numbers. Multi-arm clinical trials may be difficult to power sufficiently to test new treatments and become unrealistic. International collaboration will be required, which adds to logistical difficulties. Caution must also be exercised in the face of scientific enthusiasm, given the thus far retrospective nature of the data collected. Many factors need further consideration, such as the influence of treatment outcomes in relation to subgroups. If progress is to be made, however, and the dream of omission of craniospinal radiation realized in even a subsection of patients, then courageous jumps must be made.

\section{Summary}

We are entering an exciting new age of biology-driven treatment for both medulloblastoma and CNS-PNETs. The definition of groups of patients with molecularly distinct disease allows us to treat patients according to their biology and the potential behavior of their tumors. By defining tumors biologically we may more accurately predict behavior and be able to direct therapy accordingly. It gives us the opportunity to use targeted agents specific to biologically defined groups, and therefore gives us more chance of success. Although fast becoming a clinical reality, incorporating this new knowledge into our clinical work is challenging and requires caution, as the field is still evolving, as well as leaps of faith in order to change the face of clinical practice. Future trials will need to be intelligently balanced to capitalize on our biological successes, yet not hyper-fractionate our already small patient numbers nor compromise our current successful outcomes.

\section{Abbreviations}

ATRT, atypical teratoid rhabdoid tumor; C19MC, chromosome 19 microRNA cluster; CNS, central nervous system; ETANTR, embryonal tumor with abundant neuropil and true rosettes; FFPE, formalin fixed paraffin embedded; MBEN, medulloblastoma with extensive nodularity; MRI, magnetic resonance imaging; PNET, primitive neuro-ectodermal tumor; WHO, World Health Organization.

\section{Disclosures}

The authors declare that they have no disclosures.

\section{References}

I. Rorke LB: The cerebellar medulloblastoma and its relationship to primitive neuroectodermal tumors. J Neuropathol Exp Neurol 1983, 42:I-I5.

2. Louis D, Ohgaki H, Wiestler O, Cavenee W: WHO classification of tumours of the central nervous system. Lyon: IARC Press; 2007.

3. Pomeroy SL, Tamayo $P$, Gaasenbeek M, Sturla LM, Angelo M, McLaughlin ME, Kim JY, Goumnerova LC, Black PM, Lau C, Allen JC, Zagzag D, Olson JM, Curran T, Wetmore C, Biegel JA, Poggio T, Mukherjee S, Rifkin R, Califano A, Stolovitzky G, Louis DN, Mesirov JP, Lander ES, Golub TR: Prediction of central nervous system embryonal tumour outcome based on gene expression. Nature 2002, 4I5:436-42.

\section{FlOOOPrime} RECOMMENDED

4. Cho YJ, Tsherniak A, Tamayo P, Santagata S, Ligon A, Greulich H, Berhoukim R, Amani V, Goumnerova L, Eberhart CG, Lau CC, Olson JM, Gilbertson RJ, Gajjar A, Delattre O, Kool M, Ligon K, Meyerson M, Mesirov JP, Pomeroy SL: Integrative genomic analysis of medulloblastoma identifies a molecular subgroup that drives poor clinical outcome. J Clin Oncol 20 I I, 29:|424-30. 
5. Kool M, Koster J, Bunt J, Hasselt NE, Lakeman A, van Sluis P, Troost D, Meeteren NS, Caron HN, Cloos J, Mrsić A, Ylstra B, Grajkowska W, Hartmann W, Pietsch T, Ellison D, Clifford SC, Versteeg R: Integrated genomics identifies five medulloblastoma subtypes with distinct genetic profiles, pathway signatures and clinicopathological features. PLoS One 2008, 3:e3088.

6. Northcott PA, Korshunov A, Witt H, Hielscher T, Eberhart CG, Mack S, Bouffet E, Clifford SC, Hawkins CE, French P, Rutka JT, Pfister S, Taylor MD: Medulloblastoma comprises four distinct molecular variants. J Clin Oncol 201 I, 29:1408-14.

\section{FlOOOPrime \\ RECOMMENDED}

7. Thompson MC, Fuller C, Hogg TL, Dalton J, Finkelstein D, Lau CC, Chintagumpala M, Adesina A, Ashley DM, Kellie SJ, Taylor MD, Curran T, Gajjar A, Gilbertson RJ: Genomics identifies medulloblastoma subgroups that are enriched for specific genetic alterations. J Clin Oncol 2006, 24:1924-31.

8. Taylor MD, Northcott PA, Korshunov A, Remke M, Cho YJ, Clifford SC, Eberhart CG, Parsons DW, Rutkowski S, Gajiar A, Ellison DW, Lichter P, Gilbertson RJ, Pomeroy SL, Kool M, Pfister SM: Molecular subgroups of medulloblastoma: the current consensus. Acta Neuropathol 2012, I 23:465-72.

\section{FlOOOPrime} RECOMMENDED

9. Picard D, Miller S, Hawkins CE, Bouffet E, Rogers HA, Chan TS, Kim SK, Ra YS, Fangusaro J, Korshunov A, Toledano H, Nakamura H, Hayden JT, Chan J, Lafay-Cousin L, Hu P, Fan X, Muraszko KM, Pomeroy SL, Lau CC, Ng HK, Jones C, Van Meter T, Clifford SC, Eberhart C, Gajjar A, Pfister SM, Grundy RG, Huang A: Markers of survival and metastatic potential in childhood CNS primitive neuro-ectodermal brain tumours: an integrative genomic analysis. Lancet Oncol 2012, 13:838-48.

10. Ostrom QT, Gittleman H, Farah P, Ondracek A, Chen Y, Wolinsky Y, Stroup NE, Kruchko C, Barnholtz-Sloan JS: CBTRUS statistical report: Primary brain and central nervous system tumors diagnosed in the United States in 2006-2010. Neuro Oncol 2013, I5(Suppl 2): I-56.

\section{FlOOOPrime \\ RECOMMENDED}

II. Chang $\mathrm{CH}$, Housepian EM, Herbert C Jr.: An operative staging system and a megavoltage radiotherapeutic technic for cerebellar medulloblastomas. Radiology 1969, 93:135I-9.

12. Pfister S, Remke M, Benner A, Mendrzyk F, Toedt G, Felsberg J, Wittmann A, Devens F, Gerber NU, Joos S, Kulozik A, Reifenberger G, Rutkowski S, Wiestler OD, Radlwimmer B, Scheurlen W, Lichter P, Korshunov A: Outcome Prediction in Pediatric Medulloblastoma Based on DNA Copy-Number Aberrations of Chromosomes 6q and I7q and the MYC and MYCN Loci. J Clin Oncol 2009, 27:1627-36.

\section{FlOOOPrime RECOMMENDED}

13. Ellison DW, Kocak M, Dalton J, Megahed H, Lusher ME, Ryan SL, Zhao W, Nicholson SL, Taylor RE, Bailey S, Clifford SC: Definition of disease-risk stratification groups in childhood medulloblastoma using combined clinical, pathologic, and molecular variables. J Clin Oncol 20II, 29:1400-7.

\section{FlOOOPrime}

14. Curran EK, Sainani KL, Le GM, Propp JM, Fisher PG: Gender affects survival for medulloblastoma only in older children and adults: a study from the Surveillance Epidemiology and End Results Registry. Pediatr Blood Cancer 2009, 52:60-4.

\section{FlOOOPrime}

I5. Dhall G, Grodman H, Ji L, Sands S, Gardner S, Dunkel IJ, McCowage GB, Diez B, Allen JC, Gopalan A, Cornelius AS, Termuhlen A, Abromowitch M, Sposto R, Finlay JL: Outcome of children less than three years old at diagnosis with nonmetastatic medulloblastoma treated with chemotherapy on the "Head Start" I and II protocols. Pediatr Blood Cancer 2008, 50: I 169-75.

16. Geyer JR, Sposto R, Jennings M, Boyett JM, Axtell RA, Breiger D, Broxson E, Donahue B, Finlay JL, Goldwein JW, Heier LA, Johnson D, Mazewski C, Miller DC, Packer R, Puccetti D, Radcliffe J, Tao ML, Shiminski-Maher T; Children's Cancer Group: Multiagent chemotherapy and deferred radiotherapy in infants with malignant brain tumors: a report from the Children's Cancer Group. J Clin Oncol 2005, 23:762I-3I.

17. Grill J, Sainte-Rose C, Jouvet A, Gentet JC, Lejars O, Frappaz D, Doz F, Rialland X, Pichon F, Bertozzi Al, Chastagner P, Couanet D, Habrand JL, Raquin MA, Le Deley MC, Kalifa C; French Society of Paediatric Oncology: Treatment of medulloblastoma with postoperative chemotherapy alone: an SFOP prospective trial in young children. Lancet Oncol 2005, 6:573-80.

\section{FlOOOPrime}

18. Rutkowski SI, Bode U, Deinlein F, Ottensmeier H, Warmuth-Metz M, Soerensen N, Graf N, Emser A, Pietsch T, Wolff JE, Kortmann RD, Kuehl J: Treatment of early childhood medulloblastoma by postoperative chemotherapy alone. N Engl J Med 2005, 352:978-86.

19. Rutkowski S, von Hoff K, Emser A, Zwiener I, Pietsch T, FigarellaBranger D, Giangaspero F, Ellison DW, Garre ML, Biassoni V, Grundy RG, Finlay JL, Dhall G, Raquin MA, Grill J: Survival and prognostic factors of early childhood medulloblastoma: an international meta-analysis. J Clin Oncol 2010, 28:496I-8.

\section{FlOOOPrime
RECOMMENDED}

20. Ashley DM, Merchant TE, Strother D, Zhou T, Duffner P, Burger PC, Miller DC, Lyon N, Bonner MJ, Msall M, Buxton A, Geyer R, Kun LE, Coleman L, Pollack IF: Induction chemotherapy and conformal radiation therapy for very young children with nonmetastatic medulloblastoma: Children's Oncology Group study P9934. J Clin Oncol 30:318I-6.

\section{FlOOOPrime}

21. Albright AL, Wisoff JH, Zeltzer PM, Boyett JM, Rorke LB, Stanley P: Effects of medulloblastoma resections on outcome in children: a report from the Children's Cancer Group. Neurosurgery 1996, 38:265-71.

22. Zeltzer PM, Boyett JM, Finlay JL, Albright AL, Rorke LB, Milstein JM, Allen JC, Stevens KR, Stanley P, Li H, Wisoff JH, Geyer JR, McGuireCullen P, Stehbens JA, Shurin SB, Packer RJ: Metastasis stage, adjuvant treatment, and residual tumor are prognostic factors for medulloblastoma in children: conclusions from the Children's Cancer Group 92 I randomized phase III study. J Clin Oncol 1999, 17:832-45.

\section{FlOOOPrime}

RECOMMENDED

23. Packer RJ, Gajjar A, Vezina G, Rorke-Adams L, Burger PC, Robertson PL, Bayer L, LaFond D, Donahue BR, Marymont MH, Muraszko K, Langston J, Sposto R: Phase III study of craniospinal radiation therapy followed by adjuvant chemotherapy for newly diagnosed average-risk medulloblastoma. J Clin Oncol 2006, 24:4202-8.

\section{FlOOPrime}

\section{RECOMMENDED}

24. Gajjar A, Chintagumpala M, Ashley D, Kellie S, Kun LE, Merchant TE, Woo S, Wheeler G, Ahern V, Krasin MJ, Fouladi M, Broniscer A, Krance R, Hale GA, Stewart CF, Dauser R, Sanford RA, Fuller C, Lau C, Boyett JM, Wallace D, Gilbertson RJ: Risk-adapted craniospinal radiotherapy followed by high-dose chemotherapy and stemcell rescue in children with newly diagnosed medulloblastoma (St Jude Medulloblastoma-96): long-term results from a prospective, multicentre trial. Lancet Oncol 2006, 7:8I3-20.

25. Walter AW, Mulhern RK, Gajjar A, Heideman RL, Reardon D, Sanford RA, Xiong X, Kun LE: Survival and neurodevelopmental 
outcome of young children with medulloblastoma at St Jude Children's Research Hospital. J Clin Oncol 1999, 17:3720-8.

\section{FIOOOPrime}

26. Mulhern RK, Palmer SL, Merchant TE, Wallace D, Kocak M, Brouwers P, Krull K, Chintagumpala M, Stargatt R, Ashley DM, Tyc VL, Kun L, Boyett J, Gajjar A: Neurocognitive consequences of risk-adapted therapy for childhood medulloblastoma. J Clin Oncol 2005, 23:5511-9.

27. Moxon-Emre I, Bouffet E, Taylor MD, Laperriere N, Scantlebury N, Law N, Spiegler BJ, Malkin D, Janzen L, Mabbott D: Impact of Craniospinal Dose, Boost Volume, and Neurologic Complications on Intellectual Outcome in Patients With Medulloblastoma. J Clin Oncol 2014, 32:1760-8.

28. St Clair WH, Adams JA, Bues M, Fullerton BC, La Shell S, Kooy HM, Loeffler JS, Tarbell NJ: Advantage of protons compared to conventional X-ray or IMRT in the treatment of a pediatric patient with medulloblastoma. Int J Radiat Oncol Biol Phys 2004, 58:727-34.

29. Gandola L, Massimino M, Cefalo G, Solero C, Spreafico F, Pecori E, Riva D, Collini P, Pignoli E, Giangaspero F, Luksch R, Berretta S, Poggi G, Biassoni V, Ferrari A, Pollo B, Favre C, Sardi I, Terenziani M, Fossati-Bellani F: Hyperfractionated accelerated radiotherapy in the Milan strategy for metastatic medulloblastoma. J Clin Oncol 2009, 27:566-71.

\section{FlOOOPRIM
RECOMMENDED}

30. Jakacki RI, Burger PC, Zhou T, Holmes EJ, Kocak M, Onar A, Goldwein J, Mehta M, Packer RJ, Tarbell N, Fitz C, Vezina G, Hilden J, Pollack IF: Outcome of children with metastatic medulloblastoma treated with carboplatin during craniospinal radiotherapy: a Children's Oncology Group Phase I/II study. J Clin Oncol 2012, 30:2648-53.

\section{FlOOOPrime
RECOMMENDED}

31. Lannering B, Rutkowski S, Doz F, Pizer B, Gustafsson G, Navajas A, Massimino $M$, Reddingius $R$, Benesch $M$, Carrie $C$, Taylor $R$, Gandola L, Björk-Eriksson T, Giralt J, Oldenburger F, Pietsch T, Figarella-Branger D, Robson K, Forni M, Clifford SC, WarmuthMetz M, von Hoff K, Faldum A, Mosseri V, Kortmann R: Hyperfractionated versus conventional radiotherapy followed by chemotherapy in standard-risk medulloblastoma: results from the randomized multicenter HIT-SIOP PNET 4 trial. J Clin Oncol 2012, 30:3187-93.

32. Taylor RE, Bailey CC, Robinson KJ, Weston CL, Walker DA, Ellison D, Ironside J, Pizer BL, Lashford LS: Outcome for patients with metastatic (M2-3) medulloblastoma treated with SIOPI UKCCSG PNET-3 chemotherapy. Eur J Cancer 2005, 41:727-34.

33. Pizer B, Donachie PH, Robinson K, Taylor RE, Michalski A, Punt J, Ellison DW, Picton S: Treatment of recurrent central nervous system primitive neuroectodermal tumours in children and adolescents: results of a Children's Cancer and Leukaemia Group study. Eur J Cancer 201 I, 47:1389-97.

34. Warmuth-Metz M, Blashofer S, von Bueren AO, von Hoff K, Bison B, Pohl F, Kortmann RD, Pietsch T, Rutkowski S: Recurrence in childhood medulloblastoma. J Neurooncol 201 I, I03:705- I I.

35. Miller S, Rogers HA, Lyon P, Rand V, Adamowicz-Brice M, Clifford SC, Hayden JT, Dyer S, Pfister S, Korshunov A, Brundler MA, Lowe J, Coyle B, Grundy RG: Genome-wide molecular characterization of central nervous system primitive neuroectodermal tumor and pineoblastoma. Neuro Oncol 201 I, I3:866-879.

36. Eberhart CG, Brat DJ, Cohen KJ, Burger PC: Pediatric neuroblastic brain tumors containing abundant neuropil and true rosettes. Pediatr Dev Pathol 2000, 3:346-52.

37. von Bueren $A O$, Gerss J, Hagel C, Cai H, Remke M, Hasselblatt $M$, Feuerstein BG, Pernet S, Delattre O, Korshunov A, Rutkowski S, Pfister SM, Baudis M: DNA copy number alterations in central primitive neuroectodermal tumors and tumors of the pineal region: an international individual patient data meta-analysis. J Neurooncol 2012, 109:415-23

\section{FIOOOPrime}

38. Korshunov A, Ryzhova M, Jones DT, Northcott PA, van Sluis $P$, Volckmann R, Koster J, Versteeg R, Cowdrey C, Perry A, Picard D, Rosenblum M, Giangaspero F, Aronica E, Schüller U, Hasselblatt M, Collins VP, von Deimling A, Lichter P, Huang A, Pfister SM, Kool M: LIN28A immunoreactivity is a potent diagnostic marker of embryonal tumor with multilayered rosettes (ETMR). Acta Neuropathol 2012, I 24:875-8I.

\section{FlOOOPrime
RECOMMENDED}

39. Fangusaro J, Finlay J, Sposto R, Ji L, Saly M, Zacharoulis S, Asgharzadeh S, Abromowitch M, Olshefski R, Halpern S, Dubowy R, Comito M, Diez B, Kellie S, Hukin J, Rosenblum M, Dunkel I, Miller DC, Allen J, Gardner S: Intensive chemotherapy followed by consolidative myeloablative chemotherapy with autologous hematopoietic cell rescue (AuHCR) in young children with newly diagnosed supratentorial primitive neuroectodermal tumors (sPNETs): report of the Head Start I and II experience. Pediatr Blood Cancer 2008, 50:312-8.

40. Friedrich $C$, von Bueren $A O$, von Hoff $K$, Gerber NU, Ottensmeier $H$, Deinlein $F$, Benesch $M$, Kwiecien R, Pietsch T, Warmuth-Metz M, Faldum A, Kuehl J, Kortmann RD, Rutkowski S: Treatment of young children with CNS-primitive neuroectodermal tumors/pineoblastomas in the prospective multicenter trial HIT 2000 using different chemotherapy regimens and radiotherapy. Neuro Oncol 2013, I5:224-34.

4I. Jakacki RI, Zeltzer PM, Boyett JM, Albright AL, Allen JC, Geyer JR, Rorke LB, Stanley P, Stevens KR, Wisoff J, et al.: Survival and prognostic factors following radiation and/or chemotherapy for primitive neuroectodermal tumors of the pineal region in infants and children: a report of the Childrens Cancer Group. J Clin Oncol 1995, I3:1377-83.

42. Marec-Berard P, Jouvet A, Thiesse P, Kalifa C, Doz F, Frappaz D: Supratentorial embryonal tumors in children under 5 years of age: an SFOP study of treatment with postoperative chemotherapy alone. Med Pediatr Oncol 2002, 38:83-90.

43. McBride SM, Daganzo SM, Banerjee A, Gupta N, Lamborn KR, Prados MD, Berger MS, Wara WM, Haas-Kogan DA: Radiation is an important component of multimodality therapy for pediatric non-pineal supratentorial primitive neuroectodermal tumors. Int J Radiat Oncol Biol Phys 2008, 72:1319-23.

44. Timmermann B, Kortmann RD, Kuhl J, Rutkowski S, Meisner C, Pietsch T, Deinlein F, Urban C, Warmuth-Metz M, Bamberg M: Role of radiotherapy in supratentorial primitive neuroectodermal tumor in young children: results of the German HIT-SKK87 and HIT-SKK92 trials. J Clin Oncol 2006, 24:I554-60.

45. Chintagumpala M, Hassall T, Palmer S, Ashley D, Wallace D, Kasow K, Merchant TE, Krasin MJ, Dauser R, Boop F, Krance R, Woo S, Cheuk R, Lau C, Gilbertson R, Gajjar A: A pilot study of riskadapted radiotherapy and chemotherapy in patients with supratentorial PNET. Neuro Oncol 2009, I I:33-40.

\section{FlOOOPrime}

RECOMMENDED

46. Cohen BH, Zeltzer PM, Boyett JM, Geyer JR, Allen JC, Finlay JL, McGuire-Cullen P, Milstein JM, Rorke LB, Stanley P, et al.: Prognostic factors and treatment results for supratentorial primitive neuroectodermal tumors in children using radiation and chemotherapy: a Childrens Cancer Group randomized trial. J Clin Oncol 1995, I3:1687-96.

47. Massimino M, Gandola L, Biassoni V, Spreafico F, Schiavello E, Poggi G, Pecori E, Vajna De Pava M, Modena P, Antonelli M, Giangaspero F: Evolving of therapeutic strategies for CNS-PNET. Pediatr Blood Cancer 2013, 60:2031-5.

48. Pizer BL, Weston $\mathrm{CL}$, Robinson $\mathrm{KJ}$, Ellison DW, Ironside J, Saran F, Lashford LS, Tait D, Lucraft H, Walker DA, Bailey CC, Taylor RE: Analysis of patients with supratentorial primitive 
neuro-ectodermal tumours entered into the SIOP/UKCCSG PNET 3 study. Eur J Cancer 2006, 42: I I20-8.

49. Reddy AT, Janss AJ, Phillips PC, Weiss HL, Packer RJ: Outcome for children with supratentorial primitive neuroectodermal tumors treated with surgery, radiation, and chemotherapy. Cancer 2000, 88:2189-93.

50. Northcott PA, Korshunov A, Pfister SM, Taylor MD: The clinical implications of medulloblastoma subgroups. Nat Rev Neurol 20|2, 8:340-5।

5I. Ellison DW, Onilude OE, Lindsey JC, Lusher ME, Weston CL, Taylor RE, Pearson AD, Clifford SC: beta-Catenin status predicts a favorable outcome in childhood medulloblastoma: the United Kingdom Children's Cancer Study Group Brain Tumour Committee. J Clin Oncol 2005, 23:795 I-7.

\section{FlOOOPrime} RECOMMENDED

52. Fattet S, Haberler C, Legoix P, Varlet P, Lellouch-Tubiana A, Lair S, Manie E, Raquin MA, Bours D, Carpentier S, Barillot E, Grill J, Doz F, Puget S, Janoueix-Lerosey I, Delattre O: Beta-catenin status in paediatric medulloblastomas: correlation of immunohistochemical expression with mutational status, genetic profiles, and clinical characteristics. J Pathol 2009, 2 I 8:86-94.

\section{FlOOOPrime \\ RECOMMENDED}

53. Kool $M$, Jones DT, Jäger $N$, Northcott PA, Pugh TJ, Hovestadt $V$, Piro RM, Esparza LA, Markant SL, Remke M, Milde T, Bourdeaut F, Ryzhova M, Sturm D, Pfaff E, Stark S, Hutter S, Seker-Cin H, Johann P, Bender S, Schmidt C, Rausch T, Shih D, Reimand J, Sieber L, Wittmann A, Linke L, Witt H, Weber UD, Zapatka M, et al.: Genome sequencing of SHH medulloblastoma predicts genotype-related response to smoothened inhibition. Cancer Cell 2014, 25:393-405.

54. Taylor MD, Liu L, Raffel C, Hui CC, Mainprize TG, Zhang X, Agatep R, Chiappa S, Gao L, Lowrance A, Hao A, Goldstein AM, Stavrou T, Scherer SW, Dura WT, Wainwright B, Squire JA, Rutka JT, Hogg D: Mutations in SUFU predispose to medulloblastoma. Nat Genet 2002, 3 I:306-10.

\section{FIOOOPrime}

55. Jones DT, Jäger N, Kool M, Zichner T, Hutter B, Sultan M, Cho YJ, Pugh T], Hovestadt V, Stütz AM, Rausch T, Warnatz HJ, Ryzhova M, Bender S, Sturm D, Pleier S, Cin H, Pfaff E, Sieber L, Wittmann A, Remke M, Witt H, Hutter S, Tzaridis T, Weischenfeldt J, Raeder B, Avci M, Amstislavskiy V, Zapatka M, Weber UD, et al.: Dissecting the genomic complexity underlying medulloblastoma. Nature 2012, 488: $100-5$.

\section{FIOOOPrime}

\section{RECOMMENDED}

56. Pugh TJ, Weeraratne SD, Archer TC, Pomeranz Krummel DA, Auclair D, Bochicchio J, Carneiro MO, Carter SL, Cibulskis K, Erlich RL, Greulich H, Lawrence MS, Lennon NJ, McKenna A, Meldrim J, Ramos AH, Ross MG, Russ C, Shefler E, Sivachenko A, Sogoloff B, Stojanov P, Tamayo P, Mesirov JP, Amani V, Teider N, Sengupta S, Francois JP, Northcott PA, Taylor MD, et al.: Medulloblastoma exome sequencing uncovers subtype-specific somatic mutations. Nature 2012, 488:106-10.

\section{FlOOOPrime \\ RECOMMENDED}

57. Robinson G, Parker M, Kranenburg TA, Lu C, Chen X, Ding L, Phoenix TN, Hedlund E, Wei L, Zhu X, Chalhoub N, Baker SJ, Huether R, Kriwacki R, Curley N, Thiruvenkatam R, Wang J, Wu G, Rusch M, Hong X, Becksfort ], Gupta P, Ma J, Easton J, Vadodaria B, OnarThomas A, Lin T, Li S, Pounds S, Paugh S: Novel mutations target distinct subgroups of medulloblastoma. Nature 20I2, 488:43-8.

\section{FIOOOPrime}

\section{RECOMMENDED}

58. Northcott PA, Shih DJ, Peacock J, Garzia L, Morrissy AS, Zichner T, Stütz AM, Korshunov A, Reimand J, Schumacher SE, Beroukhim R, Ellison DW, Marshall CR, Lionel AC, Mack S, Dubuc A, Yao Y,
Ramaswamy V, Luu B, Rolider A, Cavalli FM, Wang X, Remke M, Wu X, Chiu RY, Chu A, Chuah E, Corbett RD, Hoad GR, Jackman SD: Subgroup-specific structural variation across I,000 medulloblastoma genomes. Nature 2012, 488:49-56.

\section{FlOOOPrime
RECOMMENDED}

59. Northcott PA, Hielscher T, Dubuc A, Mack S, Shih D, Remke M, AlHalabi $H$, Albrecht S, Jabado N, Eberhart CG, Grajkowska W, Weiss WA, Clifford SC, Bouffet E, Rutka JT, Korshunov A, Pfister S, Taylor MD: Pediatric and adult sonic hedgehog medulloblastomas are clinically and molecularly distinct. Acta Neuropathol $201 \mathrm{I}, \mathrm{|} 22: 23 \mid-40$.

60. Zhukova N, Ramaswamy V, Remke M, Pfaff E, Shih DJ, Martin DC, Castelo-Branco P, Baskin B, Ray PN, Bouffet E, von Bueren AO, Jones DT, Northcott PA, Kool M, Sturm D, Pugh TJ, Pomeroy SL, Cho YJ, Pietsch T, Gessi M, Rutkowski S, Bognar L, Klekner A, Cho BK, Kim SK, Wang KC, Eberhart CG, Fevre-Montange M, Fouladi M, French PJ: Subgroup-specific prognostic implications of TP53 mutation in medulloblastoma. J Clin Oncol 2013, $31: 2927-35$.

\section{FlOOOPrime
RECOMMENDED}

61. Remke M, Hielscher T, Korshunov A, Northcott PA, Bender S, Kool M, Westermann F, Benner A, Cin H, Ryzhova M, Sturm D, Witt H, Haag D, Toedt G, Wittmann A, Schöttler A, von Bueren AO, von Deimling A, Rutkowski S, Scheurlen W, Kulozik AE, Taylor MD, Lichter P, Pfister SM: FSTL5 Is a Marker of Poor Prognosis in Non-WNT/Non-SHH Medulloblastoma. J Clin Oncol 201I, 29:3852-6I.

62. Li M, Lee KF, Lu Y, Clarke I, Shih D, Eberhart C, Collins VP, Van Meter T, Picard D, Zhou L, Boutros PC, Modena P, Liang ML, Scherer SW, Bouffet E, Rutka JT, Pomeroy SL, Lau CC, Taylor MD, Gajjar A, Dirks PB, Hawkins CE, Huang A: Frequent amplification of a chrl9q I3.4I microRNA polycistron in aggressive primitive neuroectodermal brain tumors. Cancer Cell 2009, 16:533-46.

63. Pfister S, Remke M, Castoldi M, Bai AH, Muckenthaler MU, Kulozik A, von $D$ eimling $A$, Pscherer $A$, Lichter $P$, Korshunov $A$ : Novel genomic amplification targeting the microRNA cluster at I9qI3.42 in a pediatric embryonal tumor with abundant neuropil and true rosettes. Acta Neuropathol 2009, I I 7:457-64.

64. Spence T, Perotti C, Sin-Chan P, Picard D, Wu W, Singh A, Anderson C, Blough MD, Cairncross JG, Lafay-Cousin L, Strother D, Hawkins C, Narendran A, Huang A, Chan JA: A novel C I 9MC amplified cell line links Lin28/let-7 to MTOR signaling in embryonal tumor with multilayered rosettes. Neuro Oncol 2014, 16:62-7I.

\section{FlOOOPrime
RECOMMENDED}

65. Kool M, Korshunov A, Remke M, Jones DT, Schlanstein M, Northcott PA, Cho YJ, Koster J, Schouten-van, Meeteren A, van Vuurden D, Clifford SC, Pietsch T, von Bueren AO, Rutkowski S, McCabe M, Collins VP, Bäcklund ML, Haberler C, Bourdeaut F, Delattre O, Doz F, Ellison DW, Gilbertson RJ, Pomeroy SL, Taylor MD, Lichter P, Pfister SM: Molecular subgroups of medulloblastoma: an international meta-analysis of transcriptome, genetic aberrations, and clinical data of WNT, SHH, Group 3, and Group 4 medulloblastomas. Acta Neuropathol 2012, I 23:473-84.

\section{FlOOOPrime}

RECOMMENDED

66. Korshunov A, Sturm D, Ryzhova M, Hovestadt V, Gessi M, Jones DT, Remke M, Northcott P, Perry A, Picard D, Rosenblum M, Antonelli M, Aronica E, Schüller U, Hasselblatt M, Woehrer A, Zheludkova O, Kumirova E, Puget S, Taylor MD, Giangaspero F, Peter Collins V, von Deimling $A$, Lichter $P$, Huang $A$, Pietsch $T$, Pfister SM, Kool M: Embryonal tumor with abundant neuropil and true rosettes (ETANTR), ependymoblastoma, and medulloepithelioma 
share molecular similarity and comprise a single clinicopathological entity. Acta Neuropathol 2013.

\section{FlOOOPrime}

67. Kleinman CL, Gerges N, Papillon-Cavanagh S, Sin-Chan P, Pramatarova A, Quang DA, Adoue V, Busche S, Caron M, Djambazian H, Bemmo A, Fontebasso AM, Spence T, Schwartzentruber J, Albrecht S, Hauser P, Garami M, Klekner A, Bognar L, Montes JL, Staffa A, Montpetit A, Berube P, Zakrzewska M, Zakrzewski K, Liberski PP, Dong Z, Siegel PM, Duchaine T, Perotti C: Fusion of TTYHI with the CI9MC microRNA cluster drives expression of a brain-specific DNMT3B isoform in the embryonal brain tumor ETMR. Nat Genet 2013, 46:39-44.

68. Ramaswamy V, Northcott PA, Taylor MD: FISH and chips: the recipe for improved prognostication and outcomes for children with medulloblastoma. Cancer Genet 20I I, 204:577-88.

69. Shih DJ, Northcott PA, Remke M, Korshunov A, Ramaswamy V, Kool M, Luu B, Yao Y, Wang X, Dubuc AM, Garzia L, Peacock J, Mack SC, Wu X, Rolider A, Morrissy AS, Cavalli FM, Jones DT, Zitterbart K, Faria CC, Schüller U, Kren L, Kumabe T, Tominaga T, Shin Ra Y, Garami M, Hauser P, Chan JA, Robinson S, Bognár L: Cytogenetic Prognostication Within Medulloblastoma Subgroups. J Clin Oncol 2014, 32:886-96.

70. Gottardo NG, Hansford JR, McGlade JP, Alvaro F, Ashley DM, Bailey S, Baker DL, Bourdeaut F, Cho YJ, Clay M, Clifford SC, Cohn RJ, Cole CH, Dallas PB, Downie P, Doz F, Ellison DW, Endersby R, Fisher PG, Hassall T, Heath JA, Hii HL, Jones DT, Junckerstorff R, Kellie S, Kool M,
Kotecha RS, Lichter P, Laughton S, Lee: Medulloblastoma Down Under 2013: a report from the third annual meeting of the International Medulloblastoma Working Group. Acta Neuropathol 2013, I27:189-20I.

7I. Ramaswamy V, Remke M, Bouffet E, Faria CC, Perreault S, Cho YJ, Shih DJ, Luu B, Dubuc AM, Northcott PA, Schüller U, Gururangan S, McLendon R, Bigner D, Fouladi M, Ligon KL, Pomeroy SL, Dunn S, Triscott J, Jabado N, Fontebasso A, Jones DT, Kool M, Karajannis MA, Gardner SL, Zagzag D, Nunes S, Pimentel J, Mora J: Lipp : Recurrence patterns across medulloblastoma subgroups: an integrated clinical and molecular analysis. Lancet Oncol I4:1200-7.

\section{FlOOOPrime

RECOMMENDED

72. Hovestadt V, Remke M, Kool M, Pietsch T, Northcott PA, Fischer R, Cavalli FM, Ramaswamy V, Zapatka M, Reifenberger G, Rutkowski S, Schick M, Bewerunge-Hudler M, Korshunov A, Lichter P, Taylor MD, Pfister SM, Jones DT: Robust molecular subgrouping and copynumber profiling of medulloblastoma from small amounts of archival tumour material using high-density DNA methylation arrays. Acta Neuropathol 2013, 125:913-6.

73. Northcott PA, Shih DJ, Remke M, Cho YJ, Kool M, Hawkins C, Eberhart CG, Dubuc A, Guettouche T, Cardentey Y, Bouffet E, Pomeroy SL, Marra M, Malkin D, Rutka JT, Korshunov A, Pfister S, Taylor MD: Rapid, reliable, and reproducible molecular subgrouping of clinical medulloblastoma samples. Acta Neuropathol $2012,|23: 6| 5-26$ 